\title{
脊椎疾患と診断され手術された筋萎縮性側索硬化症
}

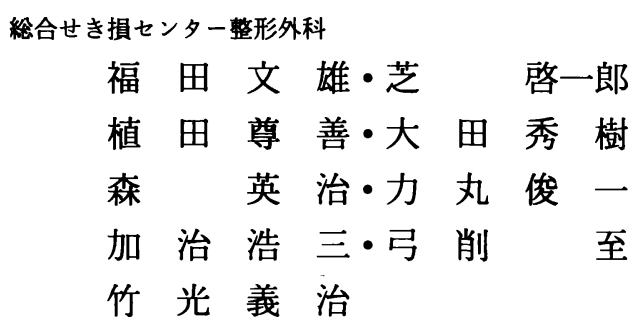

\section{Spinal Surgery for Misdiagnosed Amyotrophic Lateral Sclerosis in Spinal Diseases}

\author{
Fumio Fukuda, Keiichirou Shiba, Takayoshi Ueta, Hideki Ohta, Eiji Mori, \\ Shunichi Rikimaru, Kozo Kaji, Itaru Yuge, and Yoshiharu Takemitsu \\ Department of Orthopaedic Surgery, Spinal Injuries Center
}

Spinal operations were performed on 4 cases with Amyotrophic Lateral Sclerosis (ALS), in which 3 cases were wrongly diagnosed with cervical spondylotic myelopathy, 1 with L4 degenarative spodylolisthsis, and 1 with $\mathrm{L} 1 / 2$ disc herniation. (In 1 case, operation was performed two times for cervical lesion and lumbar lesion.) The chief complaint of all cases with obvious sensory disturbance, were muscle weakness, dullness, and numbness of the extremity. Sensory disturbance and MRI/CTM showed spinal compression slightly presenting spondylotic degenerative change were misdiagnosed. We must be careful in the evaluation of cases who have simultaneously spondylotic degenerative lesion and ALS. In all cases, post-operational symptoms were worse than pre-operational itself. We believe that the operation deteriorated the neurological states progressively and gave no benefit. In conclusion, spinal disease, with ALS or those for which ALS cannot be ruled out should not be operated.

Key words : Amyotrophic Lateral Sclerosis (筋萎縮性側索硬化症), Spinal disease (脊椎疾患), Spinal surgery（脊椎手術）

はじめに

ALS の初発症状は四肢筋力低下やシビレ・だるさ であり，感覚障害を有する症例もあり脊椎疾患との鑑 別に難渋することがある．脊椎疾患として手術される ことがしばしばあると考えられるがその報告は少なく， 今回当センターで経験した ALS 手術症例を中心にそ の診断および鑑別点, 術後経過について検討した。
対

象

頝椎症性脊䯣症：3 例, 腰椎椎間板ヘルニア：1例, 腰椎変性过り症 : 1 例と診断された（1 例は頝椎およ び腰椎の重複例)。いずれの症例も主訴は上肢または 下肢の脱力感, シビレであった（表 1 ).

\section{症 例 提 示}

症例 $1: 38$ 歳女性 
主 訴: 右下肢脱力

既往歴 : 心房中隔欠損手術後

現病歴：S62 年 8 月頃から誘因なく右膝に力が入ら
ず，右大腿がだるく感じるようになった。

入院時所見: 右深部腱反射は消失し, 右下肢全体に MMT 2 〜 筋力低下を認めたが，明らかな感覚障

\begin{tabular}{|c|c|c|c|c|c|}
\hline & 年＼cjkstart齢 & 性 別 & 診 断 名 & 式 & $\begin{array}{l}\text { 手術から ALS } \\
\text { 診断までの期間 }\end{array}$ \\
\hline 症例 1 & 38 歳 & 女性 & $\mathrm{L} 1 / 2$ 椎間板ヘルニア & L1/2 前方固定術 & 4 力月 \\
\hline 症例 2 & 50 歳 & 女性 & $\begin{array}{l}\text { L4 変性沪り症 } \\
\text { 頚椎症性脊䯣症 }\end{array}$ & $\begin{array}{l}\mathrm{L} 4 / 5 \text { 後方除圧固定術 } \\
\mathrm{C} 4 / 5 \text { 前方固定術 }\end{array}$ & 10 力月 \\
\hline 症例 3 & 60 歳 & 男性 & $\begin{array}{l}\mathrm{C} 5 / 6 \text { 椎間板ヘルニア } \\
\mathrm{C} 4 / 5 \text { 頚椎症性脊䯣症 }\end{array}$ & C4-6 前万固定術 & 6 力月 \\
\hline 症例 4 & 63 歳 & 男性 & 頚椎症性脊䯣症 & C3-7 椎弓形成術 & 1 力月 \\
\hline
\end{tabular}

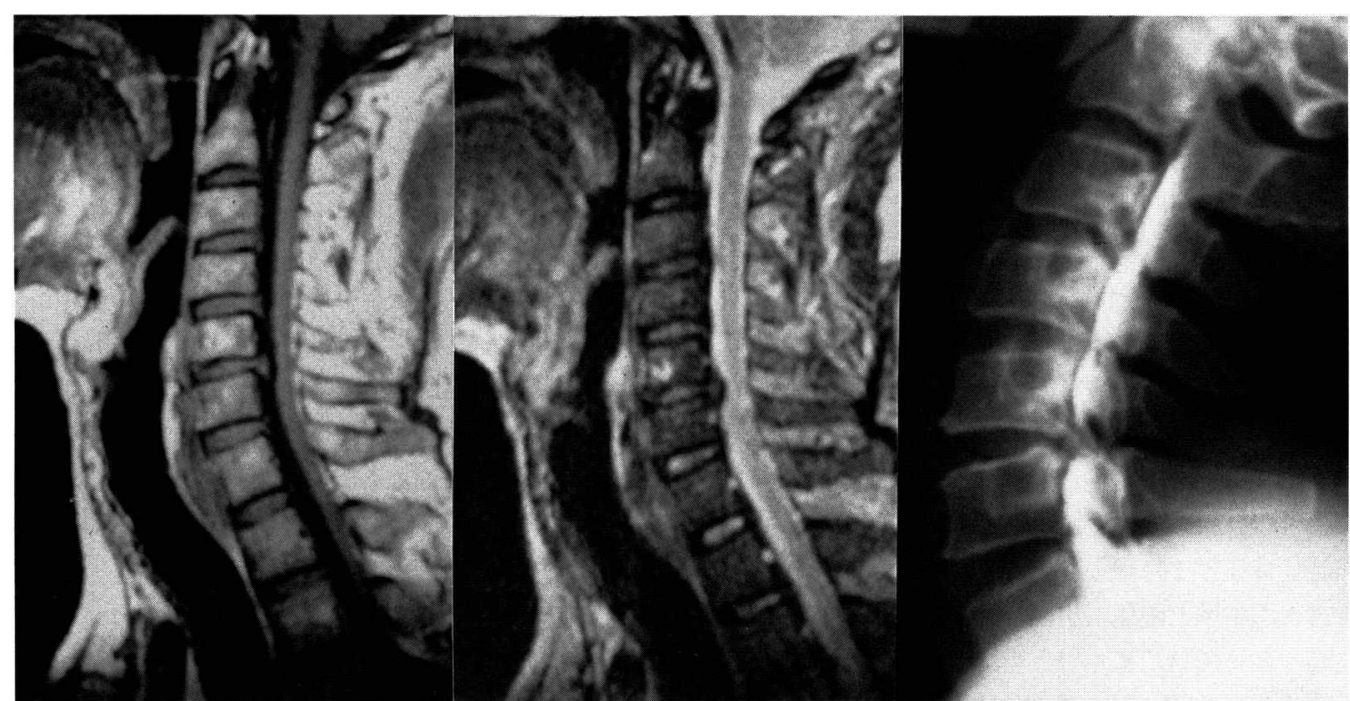

T1

$\mathrm{T} 2$

Myelogram

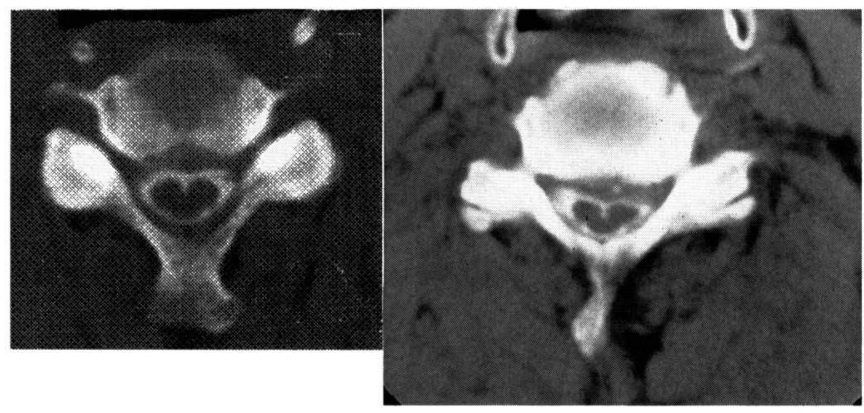

C4/5 CTM

C5/6 CTM

図 1 症例 3

C5/6レベルにヘルニアを認めるが，C4/5レベルでの脊䯣の圧迫は極軽度である. 
害はなかった，膀胱直腸障害無し．

画像所見: myelogram, discogram 等の画像にて $\mathrm{L} 1 / 2$ に軽度椎間板の膨隆を認めた。選択的脊㖪動脈 造影であ特に異常を認めなかった.

入院後経過 : L $1 / 2$ 椎間板ヘルニアと診断し前方固定 術を施行した. 術後筋力回復は認めず 4 か月後神経内 科にて ALS と診断された.

症例 $2: 50$ 歳女性

主 訴: 左下肢脱力・シビレ, 左手シビレ, 巧緻運動 障害

現病歴 : $\mathrm{S} 63$ 年 11 月頃から左下肢に力が入らず引き ずる感じがあり, 次第に左手指にもシビレ・脱力感が 出現した.

入院時所見 : 両側上下肢深部腱反射穴進, 左上下肢遠 位に MMT 2 4 の筋力低下を認めた. 左上肢内側, 左下腿に痛覚・触覚鈍麻を認めた. 膀胱直腸障害無し. 画像所見: myelogram, discogram 等の画像にて $\mathrm{L} 4 / 5$ 椎間板に変性があり軽度硬膜管の圧迫を認めた. また $\mathrm{C} 4 / 5$ レベルであ軽度脊䯣の圧迫所見を認めた。

入院後経過 : L4 変性之一り症・頚椎症性春䯑症之診断 し, まず $\mathrm{L} 4 / 5$ 後方除圧固定術を施行した. 筋力が回 復しないため, 3 か月後 $\mathrm{C} 4 / 5$ 前方固定術を施行した. 症状改善なく 7 か月後神経内科にて ALS と診断され た.

症例 $3: 60$ 歳男性

主 訴: 四肢脱力, 両上肢挙上困難, 歩行障害.

現病歴 : H 9 年 1 月両上肢に脱力を感じ 3 月頃から歩 行障害・両肩挙上困難が出現した.

既往歴 : 2 月頃話しにくいとの訴えで脳外科にて脳梗 塞と診断された既往がある.

入院時現症 : 両側上下肢深部腱反射六進, 病的反射陽 性, 両側三角筋, 上腕三頭筋, 手根伸筋, 指伸筋に MMT $3 \sim 4$ の筋力低下を認めた. 両側 C5 領域,

Th12 以下両側に痛覚過敏, 触覚鈍麻を認めた。膀胱 直腸障害無し. JOA score 10/17.

画像所見 : C5/6 レベルにヘルニアを認めるが，C4/5 レベルでの脊髄の圧迫は極軽度であった（図 1$).$

入院後経過 : $\mathrm{C} 5 / 6$ ヘルニア・C4/5 頚椎症性脊䯣症と 診断し C4-6 前方固定術を施行した. 術後一時的に知 覚障害消失し歩行も改善したが， 3 か月後両肩挙上不 能となり歩行障害も増悪した。 6 か月後舌に線維束县 縮が出現し神経内科にて ALS と診断された. 話しに くい,ご飯粒が軟口蓋にくっつきやすい等の症状があ
り球麻盘症状であったと考えられる。

症例 $4: 63$ 歳男性

主 訴: 両上肢挙上困難, 巧緻運動障害, 左䅡部痛 現病歴 : H 9 年 3 月頃から両肩挙上困難となり次第に 巧緻運動障害が出現した. 外来にて ALS を疑い某院 及び某大学病院神経内科紹介し, いずれあ頚椎症性脊 髄症と診断された。 $\mathrm{H} 9$ 年 12 月両肩挙上不能となり 入院となった。

入院時現症 : 深部腱反射光進認めず, 病的反射陰性, 両肩甲骨帯周囲筋に筋萎縮・線維束攣縮を認めた. 両 側上肢近位から遠位に MMT 2 4 の筋力低下を認め た. 両側 C8 領域および右大腿部に痛覚鈍麻を認める が触覚, 位置覚, 運動覚は正常. 膀胱直腸障害無し. JOA score $13 / 17$.

画像所見 : C3/4, C5/6 レベルで左側に軽度の脊䯣圧 迫を認める (図 2).

神経内科針筋電図検查 : 両上肢, 肩甲帯に神経原性パ ターンが認められるが, 両下肢には神経原性パターン が認められず頚椎症性脊随症と診断.

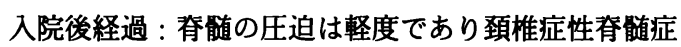
は考えにくく, 再度神経内科紹介するが再び頚椎症性 脊髄症と診断された．本人が強く手術を希望するため, ALS の場合改善が望めないことを十分説明したうえ で C3-7 椎弓形成術を施行した. 術後一時的に患者自 身両肩に力が入るようになった感じであったが, 症状 は進行し 1 か月後舌に線維束摮縮が出現し神経内科に て ALS と診断された。

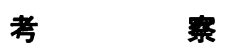

筋萎縮性側索硬化症（ALS）は上位および下位運 動ニューロンが障害され, 随意運動系のみが進行性に 障害される神経変性疾患である. 初発症状は約半数が 上肢遠位部の筋力低下で, 手指に力が入らない, 細か い動作ができない等の訴えが多い，有効な治療法に乏 しく呼吸筋に障害が及ぶと呼吸困難が出現し, 最終的 に呼吸不全で死亡する. 末期に至るまで出現しない陰 性徴候として, 明らかな眼球運動障害, 他覚的感覚障 害, 膀腅直腸障害, 小脳症状がある.一般に感覚障害 が認められないこと, 針筋電図でびまん性に神経原性 变化を認めること, 神経伝導速度や頚䯣の画像所見で 異常を認めないこと等から診断する ${ }^{1)}$. 初期にはしび れ感や痛みを認めることもあるが, 一過性であり他覚 的感覚障害は認めないとされている. しかし今回の症 


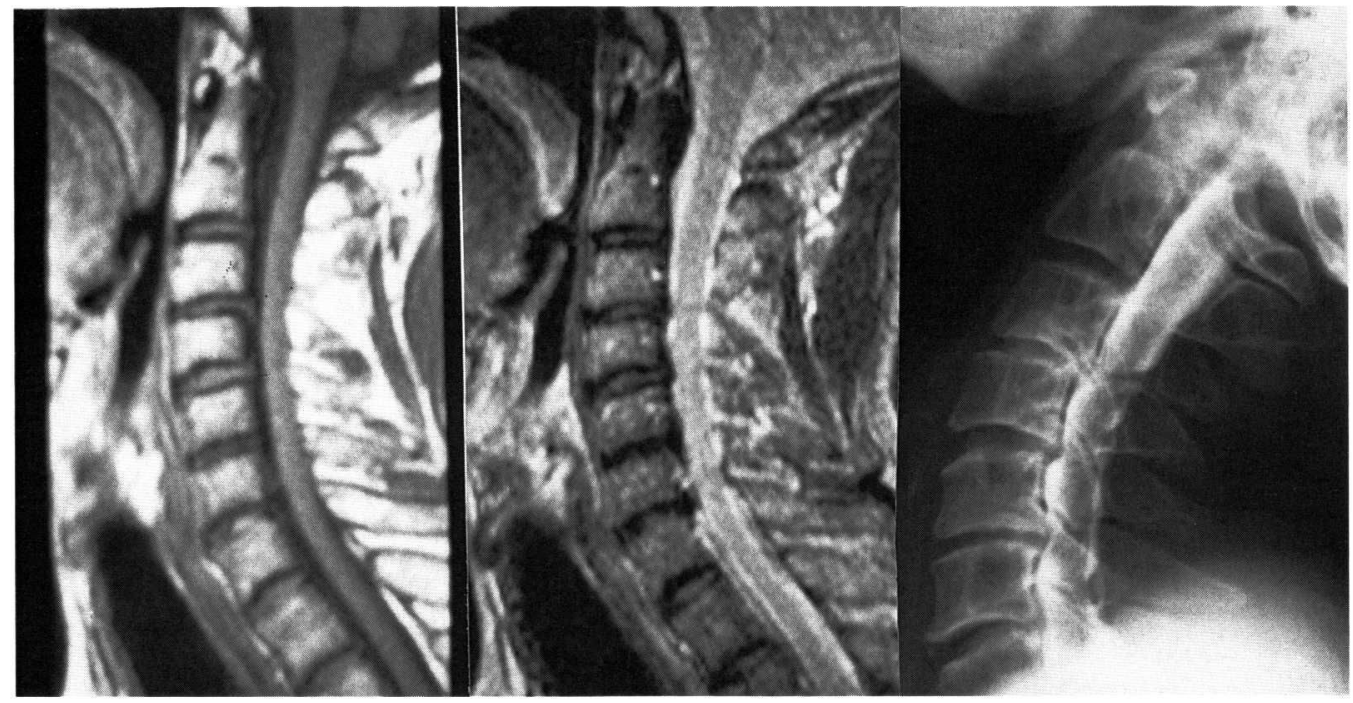

$\mathrm{T} 1$

$\mathrm{T} 2$

Myelogram

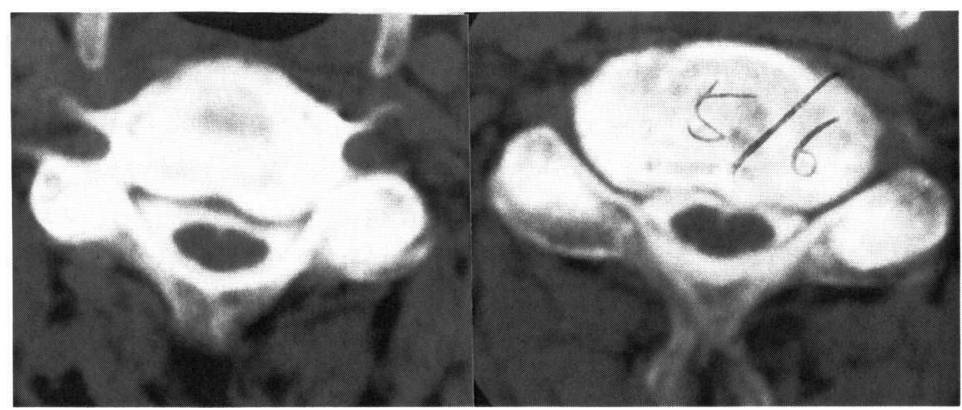

C3/4 CTM

C5/6 CTM

図 2 症例 4

C $3 / 4, C 5 / 6$ レベルで左側に軽度の脊䯣圧迫を認める.

例では患者自身シビレを自覚し，痛覚・触覚鈍麻・痛 覚過敏等の明らかな他覚的感覚障害を有しており, 脊 椎疾患との鑑別が困難であった（表 2 ）。単に患者自 身の（自覚的）シビレを他覚的感覚障害ととらえてし まったのか, 本当に感覚障害が存在するのか, ならば その病理は前角細胞や側索だけの変化ではないのか, ALS の亜型なのか，または別の病態なのか，未だ不 明である。

ALS に特異的な画像所見はなく, 錐体路徴候の著 名な例では $\mathrm{T} 2$ 強調像画像上で高信号領域が認められ ることがあるが，一般に頝䯣 MRI では異常を認めな い. ALS は中年期以降に発症し脊椎にも何らかの変 性所見が存在している時期でああり, 頝椎 X線や

\begin{tabular}{|c|c|c|c|}
\hline & $\begin{array}{l}\text { 筋萎縮・ } \\
\text { 線維束攣縮 }\end{array}$ & 感覚障害 & 画像所見 \\
\hline 症例 1 & 筋萎縮有り & 無し & 極軽度 \\
\hline 症例 2 & 無し & 痛覚 - 触覚鈍麻 & 軽度 \\
\hline 症例 3 & 無し & 痛覚・触覚鈍麻 & $\begin{array}{l}\mathrm{C} 5 / 6 \text { に有り } \\
\mathrm{C} 4 / 5 \text { 極軽度 }\end{array}$ \\
\hline 症例 4 & $\begin{array}{l}\text { 線維束攣縮・ } \\
\text { 筋萎縮有り }\end{array}$ & 痛覚鈍麻 & 極軽度 \\
\hline
\end{tabular}

MRI でみられる所見が神経徴候の原因なのか, ALS に偶然合併しているのに過ぎないのか, 判断に苦しむ 場合がある. 宇高ら ${ }^{3)}$ によるとALS 患者のうち脊椎 


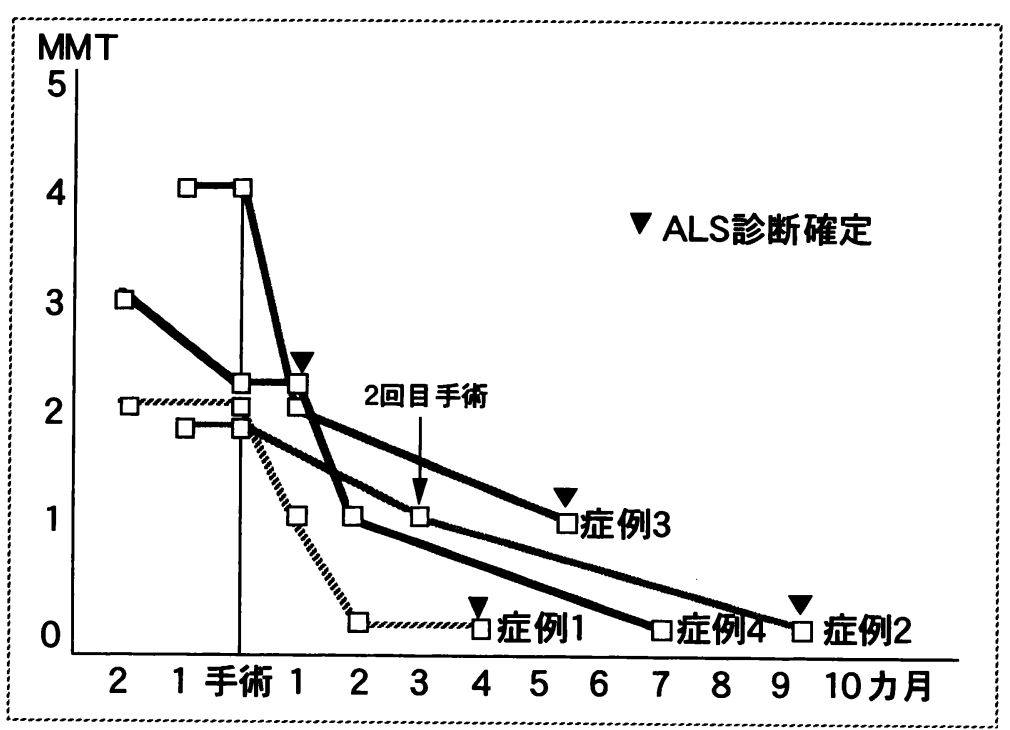

図 3 最低筋力の推移

疾患として手術された症例は，1978年から 1986 年ま では 120 例中 4 例（ $3 \% ）$ であったが, 1987 年から 1994 年までは 57 例中 5 例 $(9 \%)$ であったと報告し ている. 近年手術例が増加している原因として，脊椎 外科の進歩・普及に加え，MRI の普及により脊䯣圧 迫所見が過大評価されやすい T2 強調像により，手術 適応が決定される傾向にあるためと述べている．臨床 症状に比べ脊䯣圧迫所見が軽度な症例は診断に際し注 意が必要である（表 2 ）.

ALS と合併した脊椎疾患のように他覚的感覚障害 を認め，たまたま画像上異常所見が存在する場合が問 題である. 合併した症状のうち脊椎疾患の症状だけで あ, 手術によって脊䯑道の圧迫を解除し症状改善が期待 できるとの考えああるかもしれない. しかし症例 3 の ように手術後一時的に知覚障害が消失し步行障害も改 善したかのようにみえても 1 か月後には症状は悪化し， むしろ手術によって ALS 自身の症状を進行させてし まった（図 3 ). 手術や麻酔によって ALS の進行を 早めてしまうとの報告があるように，手術という侵襲 が臥休を早め患者の QOL を害してしまう結果とな $3^{2) 45)}$. 4 症例とも手術を契機に症状は悪化してお り, ALS と合併した脊椎疾患や ALS と鑑別できない 症例の場合は, 断じて手術を行うべきでない.
結 語

1. 脊椎疾患と診断し手術した筋萎縮性側索硬化症 4 症例について検討した.

2. 感覚障害を有していることが ALS との鑑別を 困難としていた。

3. 臨床症状に比べ画像上脊䯣圧迫所見が軽度であっ た.

4. ALS と鑑別できない症例や ALS と合併した脊 椎疾患の場合は，手術はむしろ症状を悪化させる契機 となるため行うべきでない.

\section{参 文 献}

1）藤田恒夫, 水澤英洋 : 運動ニューロン疾患. Monthly Book Orthopaedics. 9 (30): 93-98，1996.

2）井上聖啓：ALS の症状・進行様式に与える脊椎変性の 影響. 臨床神経, 31：1324， 1991.

3）宇高不可思ら：箭萎縮性側索硬化症と脊椎手術. 住友 病院誌. No.24. 110-111， 1997.

4）高橋 宏 : 神経疾患を有する頝椎病変の手術経験. 脊 椎脊䯣ジャーナル，9（7）:551-557，1996.

5）山田恭子ら：術後呼吸不全により診断された筋萎縮性 側索硬化症の 1 例. 麻䣲之蘇生. Vol.31, No.3. 209211, 1995. 